\title{
MENGEMBALIKAN POSISI SYARIKAT ISLAM DALAM MEMBANGUN JATIDIRI BANGSA INDONESIA YANG BERAKHLAKUL KHARIMAH (Kajian Dari Aspek Pendidikan )
}

\author{
Oleh: \\ Suwardie \\ Universitas Cokroaminoto Yogyakarta
}

\begin{abstract}
Abstrak
Pendidikan di Indonesia telah terkontiminasi pendidikan barat yang lebih mengutamakan kecerdasan intelektual saja, dan kecerdasan rasa dan spiritualnya terabaikan. Sejarah mencatat bahwa suatu negara dan bangsa bisa hancur bukan karena ekonomi, dan angkatan perang yang lemah, akan tetapi suatu bangsa dan negara hancur karena akhlak dan moral bangsa yang rusak. Para founders fathers RI telah menetapkan Pancasila sebagai landasan moral bagi pembentukan manusia Indonesia. Gerakan Syarekat Islam telah merumuskan sistem pendidikan yang mengangkat derajat dan martabat bangsa. Sistem pendidikan menurut gerakan Syarekat Islam tidak sekedar mencerdaskan kehidupan bangsa, tetapi menanamkan benih-benih kehidupan yang Islami yang seimbang antara kepentingan dunia dan kepentingan akhirat, memupuk jiwa persatuan dan kesatuan bangsa serta cinta tanah air.
\end{abstract}

Kata kunci: tujuan pendidikan, pendidikan moral, karakter bangsa

\section{A. Pendahuluan}

Kondisi faktual bangsa Indonesia saat ini hampir sempurna kehancurannya, karena secara sosiologis, bangsa ini telah mengalami lost generation religius (terputusnya satu generasi yang mempunyai integritas moral-agama). Secara psikologis maraknya penyakit lack of personality, sehingga mudah disulut untuk berbuat anarkisme dan sadisme. Jika realitas tersebut tidak disikapi secara profesional dan bijak, bangsa ini akan menjadi bangsa yang "gagal", karena generasi mudanya telah teracuni narkoba, miras, pengrusakan, kekerasan dan tawuran massa, 
sedangkan generasi tua (golongan ekonomi menengah keatas) telah terkontaminasi oleh "budaya" korupsi, dan selingkuh yang merupakan eksistensi kehidupan yang materialistis. Sedangkan golongan ekonomi menengah kebawah "bereforia" dengan kemiskinan dan kefakirannya, yakni rela bunuh diri dan gantung diri, melakukan aksi anarkis dan sikap sadisme, karena kehidupannya kekurangan materi dan dililit hutang ( hadist, kefakiran itu mendekatkan diri pada kekufuran). Disisi lain perilaku para elit tidak menunjukkan keteladanan selaku negarawan, kasus korupsi yang sudah menjadi tradisi para pemegang kekuasaan dan pembuat kebijakan baik di eksekutif, legislatif maupun yudikatif. Wajar, para filsuf menyatakan bahwa "ikan busuk dari kepalanya”. Secara konstektual, sikap pemimpin menjadi cermin bagi rakyatnya. Beban nasional semakin berat karena faktor eksternal, intervensi kepentingan asing dan dampak krisis global dalam berbagai aspek kehidupan. Akhirnya bangsa ini menjadi bangsa yang gagal membina tatanan moral, gagal mengentaskan kemiskinan dan terpuruk dihadapan bangsa-bangsa lain.

Berdasarkan permasalahan tersebut, salah satu alternatif mengatasi menurunnya moral bangsa adalah melalui pendidikan. Jika dilakukan secara professional, dunia pendidikan merupakan salah satu sarana pembentukan karakter bangsa yang beradab dan mulia.

\section{B. Kajian Pendidikan}

\section{Pemikiran Al Ghazali Tentang Pendidikan}

Al Ghazali disamping sebagai teolog, filosuf, kritikus, sufi, beliau juga dikenal sebagai ahli pendidikan. Menurut pemikiran Al Ghazali, pendidikan merupakan jalan utama untuk mendekatkan diri kepada Allah dalam memperoleh kebahagiaan hidup dunia dan akhirat. Persoalannya, sekarang ini pendidikan telah didistorsi menjadi alat untuk mencapai kemashuran, kedudukan dan materi semata. Karena itu, semakin tinggi tingkat pendidikan seseorang belum tentu menjadi semakin bahagia, semakin baik dan semakin taqwa kepada Allah. Bahkan sering terjadi kaum terdidik melakukan kejahatan, kekejaman kesewenang-wenangan. Kajian pemikiran Al Ghazali ini bertujuan untuk mengembalikan pendidikan dalam posisi yang sebenarnya. Pendidikan merupakan satu-satunya jalan untuk menyebarluaskan keutamaan, mengangkat harkat dan martabat manusia, dan menanamkan nilai-nilai kemanusiaan. Sehingga dapat 
dikatakan, bahwa kejayaan suatu masyarakat atau bangsa sangat bergantung sejauhmana keberhasilan dalam bidang pendidikan dan pengajaran.

Menurut Al Ghazali, pendidikan dalam prosesnya haruslah mengarah kepada pendekatan diri terhadap Allah dan kesempurnaan insan, mengarahkan manusia untuk mencapai tujuan hidup bahagia dunia dan akhirat. Pendekatan diri kepada Allah merupakan tujuan pendidikan. Orang dapat mendekatkan diri kepada Allah hanya setelah memperoleh ilmu pengetahuan. Ilmu pengetahuan itu sendiri tidak akan dapat diperoleh manusia kecuali melalui pengajaran. Secara garis besar Al Ghazali merumuskan tujuan pendidikan sebagai berikut:

a. Mendekatkan diri pada Allah, yang wujudnya adalah kemampuan dan dengan kesadaran melaksanakan ibadah wajib dan sunah.

b. Menggali dan mengembangkan potensi atau fitroh manusia.

c. Mewujudkan profesionalistis manusia untuk mengemban tugas keduniawian dengan sebaikbaiknya.

d. Membentuk manusia yang berakhlak mulia, suci jiwanya dari kerendahan budi dan jauah dari sifat-sifat tercela.

e. Mengembangkan sifat-sifat manusia yang utama sehingga menjadi manusia yang manusiawi

Kalau diperhatikan rumusan tujuan pendidikan tersebut di atas menekankan dan mengantarkan seseorang mencapai derajat "ihsan", dan ihsan adalah asas atau dasar tasawuf, membentuk manusia agar senantiasa berbuat baik (muhsin), baik kepada Pencipta, kepada diri sendiri, sesama manusia maupun lingkungan alam semesta.

\section{Pemikiran HOS Tjokroaminoto Tentang Pendidikan}

Salah satu gerakan perjuangan Sarekat Islam yang dicanangkan HOS Tjokroaminoto adalah bersandar pada ilmu pengetahuan. Hal ini sejalan dengan penghargaan yang diberikan Allah terhadap ilmu dan ahli ilmu. Lebih jauh HOS Tjokroaminoto merumuskan sistem pendidikan yang islami, menitikberatkan keseimbangan antara ilmu pengetahuan umum dengan pengetahuan agama. Selain itu pendidikan juga harus mempertebal rasa kebangsaan dan bukan sebaliknya atau mengagungkan kebudayaan asing. Untuk itu harus ada lembaga Islam yang mengelola pendidikan formal dan non formal. Pendidikan tersebut harus bertujuan untuk 
mengangkat derajat dan martabat dari setiap individu. Hal tersebut telah dibahas oleh HOS Tjokroaminoto dalam Program Asas dan Program Tandhim Sarekat Islam.

Dalam gerakannya membangun masyarakat dan bangsa Indonesia yang berbasis islami, HOS Tjoktoaminoto giat memberantas penyakit social yang merendahkan martabat pribumi. Dalam kongres di Surabaya (1913), melancarkan kampanye membasmi "tujuh M", yaitu main, madon, minum, madat, mangan, maling dan misuh. Dalam sidang khusus kongres di Bandung, Tjokroaminoto meminta perhatian khusus pendidikan yang mengadakan perubahan keadaan ekonomi rakyat kecil. Jumlah sekolah harus diperbanyak dengan mempertimbangkan pelajaran pertukangan, pertanian dan perdagangan. Lebih jauh HOS Tjokroaminoto menuangkan idenya tentang pendidikan Islam dalam artikel berjudul: "Muslim National Onderwijs". Dalam hal ini Tjokroaminoto mengemukakan prinsip-prinsip pokok dalam sistem pendidikan yang harus dilaksanakan oleh setiap warga Sarekat Islam, sebagai berikut:

a. Pendidikan dan pengajaran di sekolah-sekolah harus bermuatan dan bertujuan menjadikan sebagai muslim sejati.

b. Dalam pelaksanaan pendidikan harus ditanamkan cita-cita demokrasi sebagai sumber perjuangan dalam mengangkat derajat dan martabat bangsa.

c. Harus ditanamkan keberanian luhur, ikhlas, kesetiaan, dan kecintaan pada yang benar.

d. Ditanamkan sifat budi pekerti halus, sopan santun dan peradaban tinggi.

e. Ditanamkan prinsip hidup sederhana dan soleh dalam kehidupan beragama, bermasyarakat dan bernegara.

f. Ditanamkan prinsip yang menjunjung tinggi dan menghargai derajat dan martabat bangsa sendiri.

g. Dihubungkan dengan nasionalisme, sehingga menyebabkan pergaulan hidup dan adat istiadat kehidupan bahagia dalam rumah tangga.

h. Juga harus mampu memperkuat kecerdasan bangsa dan memupuk sikap tanggung jawab dalam kehidupan berbangsa dan bernegara.

i. Tanamkan kepada anak didik untuk tetap menjadi muslim yang baik walaupun banyak pengaruh budaya dari luar.

j. Dalam pendidikan Sarekat Islam tidak dapat dipisah-pisahkan antara ilmu pengetahuan yang berhubungan dengan keduniawian dan ilmu pengetahuan agama. 
k. Sehingga pendidikan harus dapat menghasilkan pemuda-pemudi yang dapat memahami dan terjun langsung dalam kehidupan modern dengan kemampuan penguasaan ilmu pengetahuan.

Berdasarkan prinsip-prinsip tersebut di atas, dalam membangun bangsa gerakan pendidikan Sarekat Islam tidak sekedar mencerdaskan kehidupan bangsa, tetapi juga menanamkan benih-benih kehidupan yang islami seimbang antara kepentingan dunia dan akhirat.

\section{Sistim Pendidikan Nasional}

Undang Undang Pendidikan Nasional, sejak UU NO 2 Tahun 1989, kemudian direvisi dengan UU NO 20 Tahun 2003 dengan tegas memberikan kesempatan terhormat pada pendidikan agama. Hal ini terlihat dengan jelas tujuan yang hendak dicapai yaitu manusia seutuhnya, yang ciri utamanya adalah bertaqwa kepada Tuhan YME, disamping atribut-atribut lainnya. Dalam pasal 39 ayat 2 ditegaskan bahwa bersama-sama pendidikan Pancasila dan pendidikan Kewarganegaraan, pendidikan agama menjadi kurikulum wajib bagi setiap jenis, jalur dan jenjang pendidikan. Seminar yang diadakan oleh Kementerian Pendidikan Nasional pada awal 2010 menggambarkan kebutuhan yang kuat akan pendidikan karakter dan budaya bangsa. Jika dikaji kebutuhan itu merupakan kualitas manusia Indonesia yang dirumuskan dalam tujuan pendidikan nasional.

\section{Pembahasan}

Berdasarkan pemikiran tersebut di atas, pendidikan tidak hanya menghasilkan insan yang cerdas, tetapi juga membentuk karakter yang baik. Dengan perkataan lain bahwa tujuan akhir pendidikan adalah kecerdasan yang berkarakter. Generasi masa depan harus memiliki kualitas yang seimbang antara ilmu dan kepribadian. Menurut Rene Descartes; ilmu tanpa moral adalah buta, sedangkan moral tanpa ilmu adalah bodoh". Ilmu pengetahuan tanpa moral, melahirkan politik kekerasan, politik menghabisi, politik aji mumpung, politik dagang sapi dan politik menang sendiri. Menurut Theodore Roosevelt, mendidik anak agar pandai saja tanpa mendidik moralnya bagaikan memproduksi ancaman bagi masyarakat. Karena itu tugas utama pendidikan adalah memanusiakan kembali manusia yang mengalami dehumanisasi melalui pendidikan karakter. Para founder fathers RI, Soekarno ketika mencetuskan idiologi Islam 
sebagai landasan moral, sempat mengalami benturan. Karena toleransi dan untuk menghindari perpecahan, Soekarno menawarkan Pancasila sebagai dasar Negara sekaligus landasan moral bagi pembentukan (carakter building) bangsa. Pembangunan karakter bangsa, antara lain; (a) untuk menumbuhkan dan memperkuat jati diri bangsa, (b) untuk menjaga keutuhan NKRI, dan (c) untuk membentuk manusia dan masyarakat Indonesia yang berakhlak mulia dan bangsa yang bermartabat.

Karakter adalah hati, jiwa, kepribadian, akhlak mulia, perilaku, sifat, tabiat, temperamen, atau watak. Individu yang berkarakter baik adalah seseorang yang berusaha melakukan yang terbaik terhadap Tuhan YME, terhadap dirinya, sesama, lingkungan, bangsa dan Negara serta terhadap dunia Internasional. Kehadiran nabi Muhammad saw di muka bumi ini membawa misi pokok untuk menyempurnakan akhlak manusia yang mulia, yang diwajibkan dalam agama Islam melalui nash Al Quran dan Hadis. Jika kamu berbuat baik, berarti berbuat baik bagi dirimu sendiri dan jika kamu berbuat jahat maka itu juga akan berbalik pada dirimu sendiri (Al Isro ayat 7). Sungguh dalam diri Rasulillah terdapat suri tauladan yang baik.

Hasil penelitian di Harvard University menunjukkan bahwa kesuksesan seseorang tidak ditentukan semata-mata oleh pengetahuan dan kemampuan teknis (hard skill), tetapi pada kemampuan mengelola diri dan orang lain (soft skill). Penelitian mengungkapkan, kesuksesan ditentukan hanya sekitar $20 \%$ oleh hard skill dan sisanya $80 \%$ oleh soft skill. Soft skill lebih mengarah pada perilaku sopan, disiplin, keteguhan, kemampuan kerjasama, membantu orang lain. Soft skill sangat berkaitan dengan karakter seseorang.

Berdasarkan kajian nilai-nilai agama, dan nilai Pancasila (adat istiadat dan budaya bangsa) telah teridentifikasi butir-butir nilai karakter manusia yang berhubungan dengan Tuhan YME, diri sendiri, sesama manusia, lingkungan dan kebangsaan, sebagai berikut:

a. Nilai karakter yang berhubungan dengan Tuhan

Religius: pikiran, perkataan dan tindakan seseorang diupayakan berdasarkan pada nilainilai ketuhanan/agama

b. Nilai karakter yang berhubungan dengan diri sendiri, yaitu; jujur, tanggungjawab, bergaya hidup sehat, disiplin, kerja keras, percaya diri, berjiwa wirausaha, bepikir logis, kritis dan inovatif, mandiri, ingin tahu, cinta ilmu 
c. Nilai karakter yang berhubungan dengan sesama: sadar hak dan kuajiban diri dan orang lain, patuh pada aturan sosial, menghargai karya dan prestasi orang lain, santun, dan demokratis

d. Nilai karakter dalam hubungannya dengan lingkungan: peduli sosial dan lingkungan

e. Nilai kebangsaan; nasionalis, dan menghargai keragaman

\section{Kesimpulan}

1. Berdasarkan uraian tersebut di atas, dapat ditarik kesimpulan bahwa dunia pendidikan tidak hanya membentuk insan yang cerdas, tetapi juga kepribadian atau karakter, sehingga dapat melahirkan generasi yang tumbuh dengan nilai-nilai luhur bangsa dan agama. Melalui pendidikan akan terbentuk keseimbangan antara kecerdasan intelektual, kecerdasan emosional dan kecerdasan spiritual. Istilah karakter dalam terminologi Islam lebih dikenal dengan akhlak. Akhlak suatu bangsa adalah nilai-nilai yang berhubungan dengan Tuhan YME, diri sendiri, sesama manusia, dan lingkungan yang terwujud dalam pikiran, sikap, perasaan, dan perbuatan, berdasarkan norma-norma agama, nilai-nilai yang hidup yang tumbuh dan berkembang dalam budaya dan adat istiadat masyarakat Indonesia yang Bhineka Tunggal Ika. Atau meminjam istilah ustads Zainudin MZ alh. dalam ceramahnya mengatakan" Otak boleh Jerman, hati Mekah, semangat boleh Jepang, namun kepribadian tetap Indonesia", untuk mewujudkan pribadi anak bangsa yang berakhlakul kharimah, keluarga sakinah, masyarakat marhamah dan bangsa yang bermarwah.

2. Gerakan Sarekat Islam (Tjokroaminoto) dan founder fathers RI ( Soekarno) telah menanamkan benih-benih pendidikan yang berakhlak, bertujuan membentuk insan-insan calon pemimpin bangsa yang bertaqwa kepada Tuhan YME, sekaligus menguasai Ipteks sehingga dapat tercapai pembangunan manusia seutuhnya, lahir dan batin, atau menurut terminologi Al Quran Baldatun Thoyyibatun wa Robbun Ghafuur, yaitu sebuah Negara dengan masyarakat adil dan makmur yang diridhoi Allah SWT. 


\section{E. Saran}

1. Pendidikan karakter bukanlah pendidikan yang berbasis hafalan dan pengetahuan verbal, tetapi pendidikan perilaku yang berbentuk habitual action, dan pengejawantahan melalui keteladanan para pendidik, orangtua, para pemimpin dan masyarakat.

2. Pokok-pokok pikiran dalam makalah ini perlu ditindaklanjuti dengan program action. Syarekat Islam perlu membuat Grand Design gerakan nasional untuk menyebarkan nilainilai perjuangan Syarekat Islam, konstektual sesuai kebutuhan saat ini sekaligus membangun

kaderisasi Syarekat Islam, untuk mewujudkan bangsa yang berakhlak kharimah, melalui institusi pendidikan, keluarga dan lingkungan sosial atau masyarakat luas, bahkan dapat sebagai referensi para pembuat kebijakan dan penyelenggara Negara. Semoga.

\section{Daftar Pustaka}

Abidin Ibnu Rusn, 2009, Pemikiran Al Ghazali Tentang Pendidikan, Yogyakarta: Pustaka Pelajar

Anas Salahudin \& Irwanto, 2013, Pendidikan Karakter, Bandung: Pustaka Setia.

Tjokroaminoto, Umar Said, 1995, Moeslim National Onderwiys, Tafsir Program Asas dan Tandhim Syarikat Islam dan Sosialisme, Reglemen Umum Bagi Umat Islam, Jakarta: Sekretaris Jendra Pimpinan Pusat/Lajnah Taqfidziyah Syarikat Islam.

Pupuh Fathurrohman, Suryana \& Fenny Fatriany, 2013, Pengembangan Pendidikan Karakter, Bandung: PT Rafika Aditama.

Wahjoutomo,1997, Perguruan Tinggi Pesantren: Pendidikan Alternatif Masa Depan, Jakarta: Gema Insani Press. 